\title{
Exploring New Forms of Gender Violence: Women as Objects in Plastic Surgery's Leaflets
}

\author{
María Martínez Lirola \\ University of Alicante \\ maria.lirola@ua.es
}

\begin{abstract}
There are many texts in which images of women are used for different purposes in our society. This research explores the main strategies used to create meaning in two multimodal texts used by leaflets advertising cosmetic surgery in Alicante (Spain). The study aims to point out that women are treated as objects in these leaflets. To demonstrate this argument the main visual and linguistic characteristics will be analysed in both multimodal texts in which people are persuaded of the benefits of such surgery. Special attention will be paid to the influence that the different linguistic and visual choices may have on society. This study reveals that the image of women that appears in some leaflets of this type is so aggressive that it could be understood as a new form of gender violence.
\end{abstract}

\section{Introduction: Visual Grammar as a tool to read images}

We live in a society in which we can observe the binary opposition between the masculine and the feminine, which implies a hierarchical order in which the masculine occupies a privileged position and the feminine is many times given an inferior position. Due to this situation, it is important to carry out positive actions that palliate this unfair situation in order to live in a more tolerant and respectful society.

Women are in a process of emancipation and paradoxically, this seems to result in an 'objectification' of the feminine body. Moreover, at present, it is possible for any woman to adapt herself to the beauty canon established by our society thanks to plastic surgery. Advertising contributes to the creation of reality with its discourses; this reality goes together with certain values and strategies of persuasion that try to "guide the ideological instance of the 
reader" (Reah, 2002: 50).

In this sense the concept of "biopower" should be taken into consideration. It was developed by the French sociologist Foucault (1976): 'biopower' makes reference to the practice of modern States to exploit numerous and different techniques in order to subjugate bodies and to control population, in other words, life becomes an object which is managed by power.

Advertising uses women constantly and defines them throughout hidden or direct messages that highlight that women are defined by their physical aspects (Nalon, 2000). Consequently, it seems that the values transmitted by advertising are androcentric or oriented towards men (Conboy, 2007: 125). In this way, the moral or intellectual values of women are accorded less importance. In Núñez's words ${ }^{1}$ (2003: 108-109)2

Any body can become an object. In fact, bodies adapt to society's wishes. In a society that rewards winners, what is imperfect or irregular is neglected and is moved towards the margins of what is socially acceptable. Only perfect bodies can come into the circle of what is allowed. It cannot be forgotten that perfection is defined according to certain canons. These canons delimit what is feminine and what is masculine according to our society and marginalize the bodies that do not follow the canons.

In this sense, our society can be referred to as fetishist because it accords more importance to appearance than to reality. Everything can become an object in our society (human beings and feelings) but women are especially 'objectivized' (Núñez, 2003: 112).

We live in a society surrounded by visual elements to express meaning. Baldry (2000), Kress (2003), Kress and van Leeuwen (2001) and Macken-Horarik (2004) highlight the multimodal character of present societies, where meanings are expressed throughout the combination of different semiotic resources, i.e., gestures, images and / or sound appear to express meaning together with language. As Matthiessen (2007:1) makes clear: "Multimodality - as it has come to be called - is an inherent feature of all aspects of our lives, as it has been, I believe, throughout human evolution".

Texts are always part of a social context. They "help to constitute, the contexts in which they function [and are] inseparable parts of meaning-making activities in which they take part" (Baldry and Thibault, 2006: 3). Hence, after the different resources to create meaning in both multimodal texts are analysed I will explore the relationship between texts and society and how this has an effect on the way readers perceive these texts.

This paper intends to describe and understand how different meanings are communicated through multimodal texts used by the plastic surgery clinic called Dorsia in Alicante. For this reason, I will analyse the different verbal and visual elements that create this type of text and their effect on readers. The description will concentrate on two of the seven multimodal texts used by this plastic surgery clinic to advertise their treatments during 2007.

\section{Multimodal texts}

A multimodal text is one in which we can find different elements; it uses different modes of communication: the linguistic (language) and the visual (photographs, diagrams, etc.). In 
Baldry and Thibault's words (2006:21):

The term multimodal thus recognises that, from an analytical standpoint, it is important and necessary to distinguish different classes of meaning-making resources rather than group them together as members of some more general class which fails to specify their individual characteristics.

As Martínez Lirola (2006a: 152) points out, the discourse of multimodal texts highlights modes of representation that are not written, paying especial attention to the visual mode to attract the readers' attention. Following Thibault (2000: 321), the multimodal text is understood in this paper as something that can be classified into different semiotic channels. Hence such a text is a unit in which we can observe different resources.

Each choice (linguistic and visual) has a particular purpose, a specific function in discourse. For this reason, it is necessary to understand the way in which the different visual and linguistic resources are combined to express meanings. To deepen this process of understanding, there are two basic ideas that should be taken into consideration:(1) any image creates ideas, feelings and behaviours and (2) every image has a social repercussion.

Images are crucial to guide readers to their understanding and opinion of any reality. As Borchers (2002: 165) puts it: "Like words, images are symbols that are building blocks of persuasive messages. Images communicate in ways that words cannot". In this sense, due to the fact that we need to be active participants in our society, we need to be aware of the importance of the image and, at the same time, we need to keep in mind that publicists have the power to shape or modify our attitudes of a particular fact, which would be the physical image of women in this article, because every image and every linguistic component is not chosen at random but with a clear communicative purpose, i.e., there are no innocent linguistic or visual choices.

In addition, it is necessary to take into consideration that any text does not exist independently of the readers that expand its meaning by adding their own cultural visions and attitudes. Each reader recreates the text when he/she reads or rereads it because there are no readings that are the same. This makes readers active participants in the process of reading instead of passive recipients of accepted ideas. If readers assume an active role in the creation of new meanings, this implies that the text does not convey just one meaning and that this meaning is not permanent (Beard, 2001: 4).

There is an implied reader to whom texts are addressed and from whom a determined answer, reaction or attitude is expected. This is determined by the way in which multimodal texts are created: what is included and what is excluded in them, which is outstanding and makes of that the most salient feature, how the different persons, places or things are represented, etc. The way in which texts are interpreted depends on what readers add to the text as much as on what the authors have put into the texts when they were created.

Following Martínez Lirola (2006a: 153), a good and effective multimodal text should exhibit the following characteristics:

1. The elements that create the text (verbal and non-verbal) must be complementary, i.e., they must have a close relationship. The images must be helpful to identify the context of the situation. 
2. Everything that is part of the multimodal text (type of letters, place in which the image appears, vocabulary and grammatical structures used, etc.) contributes to the creation of meaning in the text and exerts a clear and direct influence on the reader.

3. The verbal and non-verbal elements cannot be considered as two independent units that appear together. They need to be understood and read as a whole inside the text that they create.

\section{Analysis. Main linguistic and visual characteristics of the texts under analysis}

As pointed out before, this article will pay attention to how people that appear in the leaflets of this clinic are represented (colours, syntactic expressions, lexical relations, etc.). The analysis will allow me to answer the following questions: why are these texts presented in this way and not following other visual and linguistic strategies? and what is the purpose of the different choices? The basic research question is the following: what is the image of the women who appear in plastic surgery clinics leaflets in our society?

The selection of the corpus of examples is motivated by my interest in the image of women that advertising companies create in our society. The theoretical framework for the analysis is Kress and van Leeuwen's Visual Grammar (2006) and the work done by other authors such as O'Halloran (2004) and O'Toole (1994). Following Kress and van Leeuwen (2006: 177), three main aspects of composition will be considered in the multimodal texts:

- "Information value": the location in which the different elements are placed in the text, for example, from left to right, from the top to the bottom, from the centre to the margins, etc., which can add a definite value to them.

- "Salience": selected element(s) try to catch the readers' attention, for example, appearing in a prominent position, their size, the contrast in colours, or differences in sharpness.

- "Framing": the presence or absence of frames that connect or disconnect certain meanings, reinforcing whether they go or do not go together.

In addition to these aspects of the page layout, I will also consider the placement of the headings, the photograph or image, the use of colour, and the concept of prominence. Moreover, special attention will also be paid to the position of the body of the protagonist of each multimodal text, to the facial expression and to the interaction between the protagonist and other people in the image (Baldry and Thibault, 2006: 37).

All of the seven leaflets used by the plastic surgery company Dorsia during the year 2007 were collected. All of them portray a white, young woman as the protagonist. In some of these leaflets there is also a man, who is always in a predominant position and who seems to possess the woman. The article will offer a detailed analysis of two of those seven texts selected at random. The purpose of the analysis is to observe the main linguistic and visual characteristics of them and to delve into the ideology that is hidden in these texts. 


\subsection{Visual characteristics}

The way in which the page is organised guides the reader's attention to different parts of the multimodal text. The visual elements in these texts are carefully selected to persuade the reader and to show a particular view of a certain part of reality, in this case of women of different cultures (see Table 1). The following table allows us to observe the main characteristics of composition of the two multimodal texts under analysis.

\begin{tabular}{|c|c|c|}
\hline $\begin{array}{l}\text { Visual } \\
\text { characteristics }\end{array}$ & Text 1. & Text 2. \\
\hline Background & $\begin{array}{l}\text { - Dark background that contrasts } \\
\text { with the skin's colour of the } \\
\text { protagonists and with the clothes. }\end{array}$ & $\begin{array}{l}\text { - Dark background that contrasts } \\
\text { with the skin's colour of the } \\
\text { protagonists and with the clothes. }\end{array}$ \\
\hline $\begin{array}{l}\text { Layout (placement } \\
\text { of image on the } \\
\text { page) }\end{array}$ & $\begin{array}{l}\text { - The woman appears in the centre, } \\
\text { towards the left, covering almost } \\
\text { the whole page; the man appears on } \\
\text { the right. }\end{array}$ & $\begin{array}{l}\text { - The woman appears on the left } \\
\text { and the man on the right. }\end{array}$ \\
\hline $\begin{array}{l}\text { Size of the woman } \\
\text { Size of the man }\end{array}$ & $\begin{array}{l}\text { - Quite big, more than half of the } \\
\text { page. It is in the foreground. } \\
\text { - Small. It is in the foreground. }\end{array}$ & $\begin{array}{l}\text { - Quite big, more than half of the } \\
\text { page. It is in the foreground. } \\
\text { - Small. Both are in the middle } \\
\text { distance. }\end{array}$ \\
\hline Frames & - Frame: not strong. & - Frame: not strong. \\
\hline $\begin{array}{l}\text { Information value } \\
\text { (placement) }\end{array}$ & $\begin{array}{l}\text { - The main image is in the centre of } \\
\text { the page. Given and New: New } \\
\text { information appears on the left- } \\
\text { hand side of the page (it is the } \\
\text { woman). }\end{array}$ & $\begin{array}{l}\text { - Three levels. New information } \\
\text { appears on the left-hand side of the } \\
\text { page (it is the woman) and Given } \\
\text { information appear in the middle } \\
\text { distance and in the background (it } \\
\text { is the men). }\end{array}$ \\
\hline $\begin{array}{l}\text { The protagonists' } \\
\text { body expressions }\end{array}$ & $\begin{array}{l}\text { - The woman appears inclined } \\
\text { backwards and the man has her in } \\
\text { his hands. }\end{array}$ & $\begin{array}{l}\text { - The woman appears moving } \\
\text { forward, as it is clearly pointed out } \\
\text { by the vector in her right hand. }\end{array}$ \\
\hline $\begin{array}{l}\text { The protagonists' } \\
\text { facial expressions }\end{array}$ & $\begin{array}{l}\text { - The woman's facial expression } \\
\text { shows that she is enjoying, that she } \\
\text { is having pleasure. }\end{array}$ & $\begin{array}{l}\text { - The woman is smiling, she is } \\
\text { happy and relaxed at the beach. }\end{array}$ \\
\hline
\end{tabular}




\begin{tabular}{|l|l|l|}
\hline $\begin{array}{l}\text { The protagonists' } \\
\text { interaction with the } \\
\text { reader (gaze) and } \\
\text { with other people in } \\
\text { the leaflet }\end{array}$ & $\begin{array}{l}\text { - The woman interacts with the man } \\
\text { in the image because he is kissing } \\
\text { her breast and this is pleasurable } \\
\text { for her. It is only he who looks at } \\
\text { her. }\end{array}$ & $\begin{array}{l}\text { - Neither the men nor the woman } \\
\text { are looking at the reader, i.e., no } \\
\text { interaction is requested. } \\
\text { The woman does not look at the } \\
\text { readers but she interacts with } \\
\text { somebody who is not in the leaflet, } \\
\text { to whom she is offering an ice- } \\
\text { cream. The man who appears in the } \\
\text { middle distance is looking at her } \\
\text { and the man who appears in the } \\
\text { background is looking in the same } \\
\text { direction than the woman. }\end{array}$ \\
\hline Colours & - White skin (woman and man). & $\begin{array}{l}- \text { White skin (woman) and dark skin } \\
\text { (men). } \\
\text { - Green clothes. }\end{array}$ \\
\hline
\end{tabular}

Table 1. Visual characteristics of the texts analysed.

When referring to information value, it is necessary to mention known information and new information: the value of information that appears on the right and on the left.

Normally, what appears on the left is known information and what appears on the right is new information. In the two texts analysed, new information appears on the left, which implies that special attention is paid to the woman who appears in that part of the leaflet.

When talking about information value, attention should also be given to the ideal and the real: the value of information at the top and at the bottom of the page. The top of the page is more important and it normally coincides with the ideal. That is why in the two multimodal texts analysed we find there the 'end' of Dorsia: "Medicina y cirugía estética-Medicina antienvejecimiento" ("Medicine and plastic surgery-Anti-aging medicine"), which appears at the top of the page in order to persuade the reader so that he/she perceives plastic surgery as a type of medicine that encourages health. The bottom of the page normally contains real information. Therefore, here we find the main part of the bodies of the protagonists of the multimodal texts. It is worth noting that in both cases the woman's head appears in the top part of the page.

It is also necessary to refer to information in the centre and in the margins. The centre is normally the nucleus of the information. The special offers proposed by Dorsia are in the centre in Text 1; they appear forming a line with the woman's breasts and her lips. In Text 2 , there is a question in the centre that appears right on the woman's breasts. In the margins, there is information which is not so important; that is why the number of Dorsia's sanitary register number appears in the left margin.

Another characteristic of the page's layout is the most prominent element, which has to be understood as the interaction of different factors such as the colours, the place in which we find the image, the image's size, the letters' size, etc., especially paying attention to the size of the image and its relationship with the written text. It is obvious that as the previous analysis (see Table 1) has pointed out, in both texts analysed, the women is the predominant element 
because, although plastic surgery is also offered to men, it is women who are the main targets.

Finally, these texts' composition also pays attention to the frames. The presence or absence of frames that connect or disconnect elements means that those elements are or are not related. Text two contains some frames at the bottom of the page to present Dorsia's logotype and to offer the summer special.

As Kress and van Leeuwen make clear (2002: 347), the different colours used in texts, including clothes, are used to emphasize certain characteristics of the people who are represented. The selection of colours normally has an impact on the reader's feelings, which implies that he/she is requested to make an emotive response towards the text (Kress and van Leeuwen, 2002: 348).

The colours chosen for women's clothes in the two texts analysed are red (see Text 1) and green (see Text 2). Following Heller (2004), red is the colour of passions, from love to hate. The author also considers it the colour of kings and of communism, of happiness and of danger. In the text under analysis, it is obvious that red represents passion and it suits perfectly well with the woman's posture, which is clearly passionate. On the contrary, in Text 2, the woman's bikini is green. Heller (2004) makes it clear that green is the colour of fertility, of hope and of bourgeoisie, and she considers it an intermediate colour.

It is striking that Dorsia's logotype appears at the end of the page and on the left in Text 1 , while on the contrary, it appears at the end of the page and on the right in Text 2 . In the last text, the logotype is even more strongly highlighted because it appears framed and in the area of new information, i.e., on the right.

Another contrast between both images is that in the first one the woman has dark hair whereas the woman in the second text is blonde. On the contrary, the man in Text 1 is blonde and both men in Text 2 have brown hair. The woman who is the protagonist in both leaflets appears to be moving, which is crucial to add dynamism to the text; moreover, both women appear wearing glasses, with their mouths half-open, they are both white, as I have mentioned, and they possess attractive bodies. Other women are invited to have an equally good-looking body. The composition of both texts seems to imply that a nice-looking body involves being surrounded by handsome men, as it is the case in both texts. In addition, that body invites one to seduction in Text 1 and to happiness in Text 2.

\subsection{Verbal characteristics}

In what follows, I will concentrate on the verbal characteristics of the text analysed, which are summarized in the table below.

As regards the verbal characteristics of the texts analysed, the two resources that publicists working for Dorsia used most frequently are imperatives and emphatic expressions. Apart from the imperatives that appear in Table 2, other imperatives that appear in the other five multimodal texts used by Dorsia in 2007 (not analysed in detail in this article) are the following: "Be irresistible" ("Sé irresistible") or "Discover your Dorsia's side" ("Descubre tu lado Dorsia"). Other examples of emphatic expressions not mentioned in Table 2, because they belong to the texts that have not been analysed in detail, are the following: "Plastic surgery anti-aging" ("Cirugía antienvejecimiento"), "Maximum security" ("Máxima 
seguridad"), "The best price" ("Mejor precio"), "Furious present" ("Rabiosa actualidad") and "Number 1 in operations" ("Número 1 en intervenciones").

\begin{tabular}{|c|c|c|}
\hline Verbal characteristics & Text 1 & Text 2 \\
\hline Titular & $\begin{array}{l}\text { - "Dorsia's seduction. Do not } \\
\text { resist yourself" ('Seducción } \\
\text { Dorsia. No te resistas'). } \\
\text { - This is one example of } \\
\text { collocation that establishes that } \\
\text { there is one type of seduction } \\
\text { called Dorsia. There is also a } \\
\text { negative imperative used in } \\
\text { order to persuade readers. }\end{array}$ & $\begin{array}{l}\text { - "Do you know what is going to be } \\
\text { fashionable this summer?" } \\
\text { ('¿Sabes ya lo que se va a llevar } \\
\text { este verano?') } \\
\text { - This time the rhetorical device } \\
\text { used is a rhetorical question. }\end{array}$ \\
\hline $\begin{array}{l}\text { Written text } \\
\text { independent from the } \\
\text { heading }\end{array}$ & - Small size. & - Middle size. \\
\hline $\begin{array}{l}\text { Collocations and } \\
\text { emphatic expressions } \\
\text { (pondering, } \\
\text { overemphasis) }\end{array}$ & $\begin{array}{l}\text { - "Medicine anti-aging" } \\
\text { ('Medicina } \\
\text { antienvejecimiento'). }\end{array}$ & $\begin{array}{l}\text { - "Medicine anti-aging" ('Medicina } \\
\text { antienvejecimiento'). } \\
\text { - "Only in August". ('Sólo en } \\
\text { agosto'). } \\
\text { - Use of exclamations. }\end{array}$ \\
\hline Verbs & $\begin{array}{l}\text { - Absence of verbs in the } \\
\text { treatments they offer. } \\
\text { - "Do not resist yourself" ('No } \\
\text { te resistas'). } \\
\text { - There is only one verb in } \\
\text { imperative. }\end{array}$ & $\begin{array}{l}\text { - Imperatives: 'take advantage' of } \\
\text { ('aprovéchate'), 'come' ('ven'), } \\
\text { 'get information' ('infórmate'). }\end{array}$ \\
\hline
\end{tabular}

Table 2. Verbal characteristics of the texts analysed.

Although the protagonists of both texts are women and these leaflets are mainly created to persuade women, the written language is not feminized. In my view, there is a relationship of power created through the written and the spoken language, which causes readers to have the following question in mind: Is the woman the protagonist of these multimodal texts under analysis or is she just used as an answer to social expectations?

The plastic surgery leaflets that have been analysed highlight certain values which are shared by the people who 'consume' those leaflets: the image of a young, svelte and slim women (Flores Palacios, 2005: 6). Some of these leaflets show women in provoking postures, which contributes to the perception of the woman as a sexual object (see Text 1). Moreover, the represented women play an aesthetic role because they are represented as something decorative whose end seems to be to glamorise a product or a company, i.e., in this case they are used to advertise Dorsia. 


\section{Exploring texts: an approximation to 'gender visual violence'}

Once Texts 1 and 2 have been analysed taking into consideration their visual and linguistic characteristics, it is necessary to refer to the relationship between these texts and the contexts in which they are produced and consumed. This relationship has an effect on the way in which readers perceive these texts because the analysis of the different multimodal resources must always be related to the study of the context in which those texts are produced.

The printed media represent one of the crucial components in the process of the social construction of reality. They have the capacity to create representations that contribute to the making of social identities, exerting a large influence on our knowledge, our values and our social relations. For this reason, we need to become more attuned to analysing the language and visual characteristics of the media in order to develop a critical attitude. As Baeza (2001: 10) notes:

[...] a great contemporary paradox is that it is becoming common that a great number of messages do not keep us well informed. Images play a crucial place in this process, which is situated between the indifference of journalists paying attention just to the word and the increasing exploitation of visual resources that persuasive visual communication is doing.1

The selection of images affects the representation of reality. According to Leah Cross (2006: 185), "Images reflect, represent and reveal a community's values, norms, culture and history". This means that the creator of the image tries to establish a coherence between the image and the end he/she tries to achieve: moving, persuading, pitying, etc. In other words, each text contains a certain ideology, which is offered to the reader. Consequently, we need to be critical readers so that we can argue the different facts presented by advertisements.

There is a clear ideology created by the plastic surgery clinic that uses these leaflets to advertise it ('Dorsia's Ideology). This ideology is addressed to heterosexual women because there is no referent to lesbian women in the written language or in the image. This undermines women's liberation, which means that the image of women as objects that serve or please men is perpetuated.

It should be kept in mind that it is the photographer who decides what part of reality he/she wants to transmit every time, and for that reason, those images or those pieces of news are always a partial vision of reality. This makes that we, those receiving the information or the images, are just consumers of what has been selected by the photographer. Due to this, consumers should not reach conclusions regarding the total reality just by observing the fragmented reality offered by the image.

Images are representations that express certain meanings. The photograph is the central element in the narrative used by the magazine print media. It situates the context of the text and sometimes it is the first contact of a reader with a multimodal text. Being able to read the underlying meanings of multimodal texts, like the covers of magazines, implies that we need to be critical readers to know what is hidden behind each choice that creates the text. As Martínez Lirola (2006a: 166) explains:

The different choices found in the texts ... - the letters type (capital, bold, etc.), the size, the 
colours, the different ways in which elements are placed in multimodal texts (at the top or at the bottom, on the right or on the left) have an effect on the creation of meanings and it affects our attention when reading a page because there is normally a hierarchical relationship between the elements.

In this sense, the visual aspects of multimodal texts should be understood as framed in the social context in which the texts are 'consumed'. The person who designs the text does it carefully and with a very clear idea of what the text is intended to do to the reader, what the reader should see in the first place and the ideas the text will transmit because of the way it was created; in Martínez Lirola's words (2006b: 254): "[...] the designer is influenced by the social circumstances in which the text is composed, and because he/she also considers the circumstances in which these texts will appear and do their job".

The main reasons to undergo plastic surgery are the following: social, physical or psychological. For example, somebody might opt for plastic surgery due to a difficulty with corporal distortion (dismorfia corporal), i.e., when the patient believes he/she has a physical defect that does not exist or that, being real, it worries him/her too much, when it can even create an addition to plastic surgery.

In my opinion, the texts analysed are appropriate for one to talk about a new form of gender violence; therefore, in the same way that van Leeuwen (2000: 333) talked about "visual racism', I would like to point out that the texts analysed are good examples of what I will call 'gender visual violence', a case of visual violence in which women are treated as objects of desire. In general, gender violence can be perpetrated in different ways (Diputación de Alicante, 2005: 14):

- Fashion and sexual social myths (the type of violence I have referred to in the previous paragraph would be included here).

Verbal aggression.

Sexual harassment.

Forced prostitution.

Tolerated misogyny.

Hardly any representation or social influence.

Violation.

Forced abortion.

Mobbing.

Mutilations.

Emotional abuses.

In 1994, the Institute of Women from the Ministry of Work and Social Issues created the Observatory of Sexual Advertisement, whose purpose was to respond to the increasing social concern related to the image of women used in many advertisements. This Observatory is intended to work in favour of sensitisation and conscience: the eradication of sexual contents that involve dependence, subordination and violence against women.

According to the report of the Observatory of Sexual Advertisement from 2005, 400 complaints were filed because they used women's figures as advertisements or object of 
desire. This violates the Integral Law against Gender Violence (Disposición Adicional Sexta de la Ley Orgánica de Medidas de Protección Integral contra la Violencia de Género) $(1 / 2004,28 \text { de December })^{4}$ :

It is illicit advertising that goes against the dignity of the person or that injures the values and rights
established in the Constitution, especially those referred to in articles 18 and 20 , section 4 . It is
understood that this section includes advertisements that represent women in a humiliating way,
either using their bodies or parts of them particularly or directly as an object free from the product
that they are trying to promote, or using women's image associated with stereotyped behaviours
that injure the principles established in law in such a way that they could contribute to generating
the type of violence explained in the Integral Law for integral measures of protection against
gender violence.

This law deals with gender violence from many different points of view for the first time: education, health, labour, advertisement, penal and judicial. This law, as is true of any law, could be improved but it is a good instrument to fight against gender violence and discrimination.

\section{Conclusions}

The sorts of multimodal texts analysed have a clear interpersonal purpose: the different texts in which women appear in plastic surgery leaflets create a particular image of this group of the population and we should consider to what extent they persuade the reader to desire the same image, i.e., women should be slim, beautiful and the body should be perfect.

Images are created to maintain certain expectations in our society: special attention should be given to the body and one needs to be young as long as possible or at least to look young. Often images are manipulated through bright, colour, contrasts, direction or light intensity, which means that 'unreal' women try to persuade 'real' women to be like them.

I have paid attention to the way in which language and images are organized to create meaning in the texts under analysis. These meanings are influenced by the social and cultural context in which they are interchanged because they intend to portray a specific image of women: an image that shows them with a perfect body in order to please men. In this sense women are subordinated to men: they are represented as victimized and inferior to men.

Social pressure more often affects women than men, especially in aesthetic issues. For this reason, the texts analysed contribute to androcentrism because women are obliged to please men with their bodies and they must follow certain aesthetic canons already established by society. Some women feel they do not belong to the group if they do not obey these canons, and they risk their lives in plastic surgery in order to change their bodies. In this way, their physical image adapts to the patterns that have been socially established. In fact, $15 \%$ of adolescents are already receiving plastic surgery and $50 \%$ of women make it clear that they are not happy with their physical appearance and they would undergo plastic surgery if they had the money.

Consequently, giving so much importance to the feminine body makes it possible to talk 
about a kind of symbolic violence, which can be considered as ideologically accepted, i.e., it points out the recognition of masculine domination by those who are dominated. This emphasizes that egalitarian power relationships do not exist because the feminine sex is considered inferior to the masculine or at least it is given different values. It is thus necessary to request a commitment from advertising companies to portray a different image of women and employ a different type of multimodal discourse.

\section{Notes}

1. The quotations that are originally in Spanish, such as the following one, are translated by the author.

2. The original of this quotation is the following: "Cualquier cuerpo puede convertirse en objeto. De hecho, los cuerpos se adaptan a los deseos que impone la sociedad. En una sociedad que premia a los ganadores lo imperfecto, lo irregular se aborrece y se desplaza hacia los márgenes de los socialmente aceptable. Sólo entran en el círculo de lo permitido los cuerpos perfectos. Y no hemos de olvidar que la perfección se define según cánones determinados. Estos cánones delimitan lo que es femenino y lo que es masculino según nuestra sociedad, y marginan los cuerpos que no se adaptan". (Núñez, 2003: 108-109).

3. The original of this quotation is the following: “[...] una enorme paradoja contemporánea es que cada vez más un mayor número de mensajes nos tiene peor informados. Y la imagen juega un papel determinante en este proceso, situada entre la indiferencia de los periodistas de la palabra y la explotación creciente de los recursos visuales que está haciendo la comunicación persuasiva”. (Baeza, 2001: 10).

4. The original of this quotation is the following: "Es ilícita la publicidad que atente contra la dignidad de la persona o vulnere los valores y derechos reconocidos en la Constitución, especialmente a los que se refieren sus artículos 18 y 20, apartado 4 . Se entenderán incluidos en la previsión anterior los anuncios que presenten a las mujeres de forma vejatoria, bien utilizando particular y directamente su cuerpo o partes del mismo como mero objeto desvinculado del producto que se pretende promocionar, bien su imagen asociada a comportamientos estereotipados que vulneren los fundamentos de nuestro ordenamiento coadyuvando a generar la violencia a que se refiere la Ley Orgánica de medidas de protección integral contra la violencia de género".

\section{References}

Baeza, P. (2001): Por una función crítica de la fotografía. Barcelona: Gustavo Gili.

Baldry, A. (ed.) (2000): Multimodality and Multimediality in the Distance Learning Age. Campobasso: Palladino Editore.

Baldry, A. and P.J. Thibault (2006): Multimodal Transcription and Text Analysis. London: Equinox. Beard, A. (2001): Texts and Contexts. Introducing Literature and Language Study. London/New York: Routledge.

Berbel Sánchez, S. and T. Pi-Sunyer Peyrí (2001): El cuerpo silenciado. Una aproximación a la identidad femenina. Barcelona: Viena Ediciones.

Borchers, T. A. (2002): Persuasion in the Media Age. Boston: Mc Graw Hill.

Conboy, M. (2007): Language of the News. London: Routledge. 
Diputación de Alicante (2005): Hay otro camino. Guía alternativa sobre la violencia contra la mujer. Alicante: Diputación de Alicante.

Flores Palacios, M.L. (2005): "Representación de la mujer en anuncios de revistas comerciales mexicanas". Global Media Journal 2 (4): 1-22.

Foucault, M. (1976): Historia de la sexualidad. Vol. I. La voluntad de saber. Madrid: Siglo XXI Editores.

Heller, E. (2004): Psicología del color. Cómo actúan los colores sobre los sentimientos y la razón. Barcelona: Gustavo Gili.

Kress, G. (2003): Literacy in the New Media Age. London: Routledge.

Kress, G. and T. van Leeuwen (2001): Multimodal Discourse: The Modes and Media of Contemporary Communication. London: Arnold. . (2002): "Colour as a Semiotic Mode: Notes for a Grammar of Colour". Visual Communication 1 (3): 343-368.

. (2006): Reading Images: The Grammar of Visual Design. Second edition. London: Routledge Press.

Leah Cross, J. (2006): "Icons as Ideology. A Media Construction". In Lassen, I, J. Strunck and T. Vestergaard, eds., Mediating Ideology in Text and Image. Ten Critical Studies. Amsterdam/Philadelphia: John Benjamins, 173-192.

Ley Orgánica de Medidas de Protección Integral contra la Violencia de Género, 1/2004 de 28 de diciembre.

Macken-Horarik, M. (2004): "Interacting with the Multimodal Text: Reflections on Image and Verbiage in ArtExpress". Visual Communication 3 (1): 5-26.

Martínez Lirola, M. (2006a): "Una aproximación a la imagen del inmigrante en los textos multimodales de la prensa alicantina. ¿Estereotipos o realidad?". In C. Gómez Gil, ed., Otras miradas sobre la inmigración. Alicante: University of Alicante, 151-174.

. (2006b): “A Systemic Functional Analysis of Two Multimodal Covers". Revista Alicantina de Estudios Ingleses. Special Issue on Linguistics and the Media 19: 249-260.

Matthiessen, C.M.I.M. (2007): “The Multimodal Page: A Systemic Functional Exploration”. In T. D. Royce and W. L. Bowcher, eds., New Directions in the Analysis of Multimodal Discourse. London: Lawrence Erlbaum Associates, 1-63.

Nalon, E. (2000): "Multimodal Meaning Making: Perfume Advertisements and the Human Body". In A. Baldry, ed., Multimodality and Multimediality in the Distance Learning Age. Campobasso: Palladino Editore, 213-225.

Núñez, S. (2003): "En brazos de la mujer fetiche: Nacimiento y pervivencia de la imagen de la mujer como fetiche”. In J. Santaemilia, ed., Género, lenguaje y traducción. Actas del Primer Seminario Internacional sobre Género y Lenguaje. Valencia: Universidad de Valencia, 108-134.

O’Halloran K.L. (ed.) (2004): Multimodal Discourse Analysis. Systemic Functional Perspectives. London: Continuum.

O'Toole, L. Michael. (1994): The Language of Displayed Art. London: Leicester University Press. Reah, D. (2002): The Language of Newspapers. Second edition. London: Routledge.

Thibault, P.J. (2000): "The Multimodal Transcription of Television Advertisement: Theory and Practice". In A. Baldry, ed., Multimodality and Multimediality in the Distance Learning Age. Campobasso:Palladino Editore, 311-385.

van Leeuwen, T. (2000): “Visual Racism”. In M. Reisigl and R. Wodak, eds., The Semiotics of Racism. Approaches in Critical Discourse Analysis. Wien: Passagen Verlag, 333-350. 


\section{Appendix: Images}
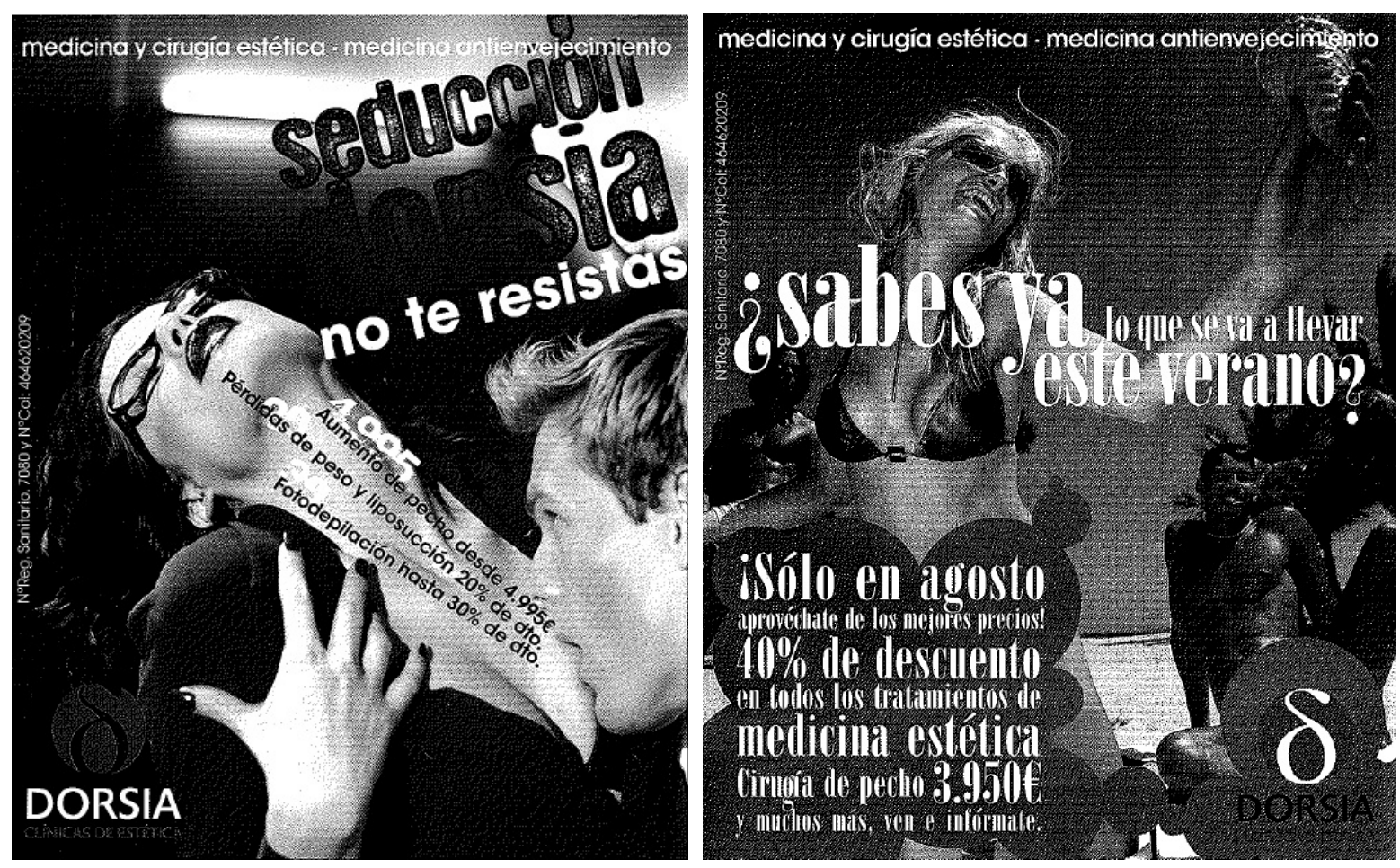

Image 1

Image 2 